\title{
The Prosecution Service Function within the Spanish Criminal Justice System
}

\author{
Marcelo F. Aebi • Marc Balcells
}

Published online: 6 August 2008

(C) Springer Science + Business Media B.V. 2008

\begin{abstract}
The national criminal justice system of Spain is described. Special attention is paid to the function of the Public Prosecution Services within this framework and its relationship to police and courts. The article not only refers to legal provisions but to the factual handling of criminal cases as well.
\end{abstract}

Keywords Country report Spain · Criminal justice system · Factual handling · Legal provisions $\cdot$ Public prosecution

\section{General Overview of the Spanish Criminal Justice System}

Introduction

The Spanish judicial system is independent and headed by the Supreme Court (Tribunal Supremo), which is the country's highest tribunal except for constitutional questions, for which there is a Constitutional Court (Tribunal Constitucional). The General Council of the Judicial Power (Consejo General del Poder Judicial) governs the Judicial Power.

Spain has a civil law system - by opposition to the common law applied, for example, in the United Kingdom - based on the Roman foundations of the iuris dictio. The criminal procedure

\footnotetext{
M. F. Aebi $(\bowtie)$

Department of Political Science and Public Law, Area of Criminal Law, Universitat Autònoma de Barcelona, Building B, Campus of the UAB, 08193 Bellaterra (Cerdanyola del Vallès), Spain

e-mail: Marcelo.Aebi@unil.ch

M. F. Aebi

Institute of Criminology and Criminal Law, University of Lausanne, ESC-ICDP-Sorge-BCH, CH-1015 Lausanne, Switzerland

M. Balcells

Department of Political Science and Public Law, Universitat Autònoma de Barcelona,

Building B, Campus of the University of Barcelona, 08193 Bellaterra (Cerdanyola del Vallès), Spain e-mail: Marc.Balcells@campus.uab.cat
} 
is governed by the legality principle - by opposition to the opportunity or expediency principle - which implies that prosecution must take place in all cases in which sufficient evidence exists of the guilt of a suspect. The Code of Criminal Procedure (Ley de Enjuiciamiento Criminal, CCP) was originally adopted in the 19th century and has been modified frequently. Since 1988, the main goal of the modifications to the CCP has been to reduce the length of the procedures by introducing abbreviated and simplified proceedings for some offences. The current Criminal Code (Código Penal) is heavily influenced by the German penal doctrine. It was adopted in 1995 and has been modified many times since then.

\section{Organization of the Courts of Justice}

Courts of justice are organized according to two interrelated criteria: hierarchy and territoriality. In that context, it must be mentioned that Spain is formed by 50 provinces integrated in 17 Autonomous Communities, as well as two autonomous cities (Ceuta and Melilla, in Northern Africa). Thus, the political organization of the country has four basic levels: State, Autonomic, Provincial and Municipal. The organization of the courts reflects these levels. However, before presenting the different courts at these levels, it must be mentioned that the competences regarding the Judicial Power has not been delegated by the Central Government to the Autonomous Communities. This means that - contrary to some federal countries who have different Judicial Powers - in Spain there is only one Judicial Power.

At the municipal level, one can find the Investigative Courts (Juzgados de Instrucción), headed by an Examining Magistrate (Juez de Instruction, EM), where the criminal proceedings usually start. When the number of inhabitants of a town is a smaller than the one established by law, the Investigative Courts are replaced by Peace Courts (Juzgados de $\mathrm{Paz}$ ), which have more or less the same functions. Also at the municipal level there are Criminal Courts (Juzgados de lo Penal), headed by a Criminal Judge (Juez de lo Penal), which are responsible of the trial stage of the criminal proceedings-i.e. after the investigative stage headed by the EM is over - and are located in capitals and big cities. If the offence being judged is punishable with a custodial sentence of 5 years imprisonment or more, the trial stage takes place before a collegiate court $^{1}$ with jurisdiction over the Province (Provincial Audience) or over the whole Autonomous Community (Superior Court of Justice).

In that context, at the provincial level one can find the Provincial Audiences (Audiencias Provinciales), which usually act as the second instance court in criminal trials or as the first instance when the offence is a Less Serious Crime (see below the Chapter on Classification of Offences). They are also responsible for the organization of the trials by jury.

At the Autonomic level, each Autonomous Community has a Superior Court of Justice (Tribunal Superior de Justicia) that deals with cassation appeals in criminal proceedings or act as the first instance court in the criminal trial when the offence is a Serious Crime (see below the chapter on Classification of Offences).

Finally, nationwide, one can find the Supreme Court and the National Audience (Audiencia Nacional). The latter has a Criminal Court (Sala de lo Penal) that deals with key offences such as terrorism and organized crime.

\footnotetext{
${ }^{1}$ Courts receive their name taking into account the number of judges that composed them. In that context, one distinguishes between courts with a single judge (Juzgados) and courts with more than one judge (Audiencias or Tribunales). Members of collegiate courts are called Magistrates (Magistrados) instead of Judges (Jueces).
} 
Main Stages of the Criminal Proceedings

According to the principles that rule the Spanish Criminal Justice System, the different criminal proceedings have more or less the same structure, which can be divided in three stages and is presented here in a simplified way.

- Investigative stage (Instrucción): All the suspected criminal offences discovered by or reported to the police are transmitted to the Examining Magistrate (EM). The EM is responsible for the investigation of them and for the preparation of the trial. The length of this stage depends on the case. It can conclude in only two ways: the dismissal of the case (sobreseimiento) or the opening of the trial stage. The law also foresees the possibility of starting the proceedings by reporting the offence directly to the Public Prosecution Services (PPS) but, as it will be explained later (see below the chapter on The Relations between the Police, the PPS and the EM), this possibility is seldom use by the public.

- Trial stage: The trial - including the verdict and the sentence - is conducted by a Criminal Court. The only exceptions to this rule concern the misdemeanours' trial and the "ultra-fast" trial, which will be discussed later. The proceedings are in principle public, and the contradiction between the different parts is guaranteed.

- Execution stage: If the court imposes a sanction, the latter is served during this stage. The execution on non-custodial sanctions is supervised by the court that imposed the sanction. In contrast, the execution of custodial sanctions is surveyed by a Judge of Penitentiary Surveillance (Juez de Vigilancia Penitenciaria). These judges are also responsible for controlling the penitentiary authorities as well as the respect of the prisoners' rights. There can be several judges of penitentiary surveillance in one province and, interestingly enough, they can cumulate this function with another position as judges in a different court of the criminal justice system.

\section{Classification of the Offences}

In Spain, there are four types of offences. The type of offence defines the kind of criminal proceeding that will be applied (the different types of criminal proceedings will be presented later) as well as the sanctions that can be imposed. The four types of offences are the following.

- Administrative Offences (infracciones administrativas): These offences are not included in the Criminal Code but in Administrative Laws. They include, for example, minor disturbances of the public order (e.g. noises), minor tobacco and alcohol smuggling by individuals, and minor speed driving. Administrative offences are sanctioned with fines imposed directly by the administrative authorities (e.g. police, customs, and tax authorities).

- Misdemeanours (faltas): These are minor offences which are punished with noncustodial sanctions and measures. As we will see, the misdemeanours' trial (juicio de faltas) has fewer formalities than the standard trial.

- Less Serious Crimes (Delitos menos graves): These offences are punishable with imprisonment up to 9 years. If the potential sanction is lower than 5 years imprisonment, the trial takes place before a criminal court (Juzgado de lo penal) composed by a single judge; if it goes from 5 to 9 years, the trial takes place before a collegiate court (Provincial Audience or Superior Court of Justice). In both cases, the trial follows the rules of the Abbreviated Proceeding (Procedimiento abreviado). If the potential sanction 
is lower than 3 years imprisonment, the proceeding can take the form of a Fast Trial (Juicio Rápido).

- Serious Crimes (Delitos graves): These offences are punishable with imprisonment for more than 9 years. The trial always takes place before a collegiate Court (Provincial Audience or Superior Court of Justice) and according to the ordinary proceeding (Sumario).

\title{
The PPS Function and Structure within the Spanish Criminal Justice System ${ }^{2}$
}

\author{
Main Role of the Spanish Public Prosecution Services (PPS)
}

The Spanish criminal procedure is based on the accusatory principle which states that a different body from the one investigating the facts (EM) and the one judging them (Criminal Court) must make the accusation in the name of the State (PPS). This principle obliges the State when accusing, not to judge; and when judging, not to accuse. It also explains the particular role played by the PPS in the Spanish criminal proceeding, which is quite different from the one played by most Western European PPS.

Indeed, rather than directing the investigative stage of the proceeding (a role played by the EM), the main function of the PPS is to formulate the accusation during the trial. Thus, even if the PPS has some privileges (e.g. it is considered as having the same hierarchical status as a judge), it is basically a part in the process, and therefore has similar rights to the other parts of the process such as the private accuser or the defence lawyer.

In practice, criminal offences are discovered or reported to the police, who transmit them to an EM and to the PPS. This is the beginning of the investigative stage of the proceeding and, during this stage, the PPS can only ask the EM to perform certain proofs. The final decision belongs to the EM, who-according to the law regulating the judicial power (Organic Law 6/1985, art. 87.1) - is in charge of the investigative stage. During the trial stage, the PPS presents the accusation before the Court and, eventually, appeals the sentence imposed.

With the exception of the offences related to the private sphere - such as injuries or calumnies -, the PPS decides to accuse or to ask for an acquittal in all cases, even if there are other accusing parts. In the case of the offences related to the private sphere, the Criminal Code states that only private accusers can intervene. This means that such offences can only be prosecuted by the victim assisted by a private accuser (a lawyer of his/her own). However, if the victim is a minor or a mentally impaired person, the PPS must intervene.

\section{Legal Basis}

Since the adoption of the current Constitution in 1978, the Spanish Public Prosecution Service (Ministerio Fiscal, PPS) is considered an autonomous body belonging to the Judicial Power. According to the Constitution (art. 124) the PPS is responsible for "promoting the action of Justice in defence of the legitimate rights of the citizens and of the public interest, assuring the independence of the tribunals, and satisfying the social interests". The PPS has to accomplish these tasks according to a series of principles that

\footnotetext{
${ }^{2}$ For a detailed presentation of the Spanish PPS, see Conde-Pumpido (1999), de la Oliva et al. (2005), Flores-Prada (1999), and Ramos-Méndez (1997, 2000).
} 
will be explained in the following chapter. In the criminal proceedings, the PPS has to exercise the penal action and also, whenever the victim does not so, the civil action (i.e. a civil procedure in order to obtain a compensation for the damages produced by the offence).

The functions and organization of the PPS are developed in Law 50/1981, which constitutes its Organic Statute. However, neither this statute nor the Constitution quoted before include a clear inventory of the different functions of the PPS. In fact, the different laws mentioning the PPS include mainly generic statements such as the one pointing out that the PPS is responsible for "satisfying the social interests".

\section{Principles Governing the PPS Tasks}

According to the Spanish Constitution, the PPS has to accomplish its tasks according to the principles of hierarchy, unity, legality and impartiality. These principles are developed in the Organic Statute of the PPS.

The principle of unity means that the PPS constitutes a unique body through all the country. A contrario, this implies that the competences regarding the public prosecution has not been transferred to the Autonomous Communities. This is the logical consequence of the fact that in Spain there is only one Judicial Power.

The principle of hierarchy means that members of the PPS must respect the chain of command. The hierarchy of the bodies of the PPS is presented in the next chapter.

The goal of the principles of unity and hierarchy is to achieve uniform criteria in the interpretation of the law and to assure the continuity of the activities of the PPS independently of the changes in their membership through time.

The principle of legality states that the PPS has to act according to the Constitution, the laws and the rest of the rules that constitute the Spanish justice system.

Finally, the principle of impartiality means that the PPS has to act with full objectivity and independence in the defence of the citizens' interests.

The logical consequence of putting these principles in relation with the PPS task of presenting the accusation during the trial is that the PPS in not obliged to present systematically a formal accusation. Indeed, the PPS can also ask for an acquittal whenever they consider that it is the right thing to do (e.g. if the proofs suggest that the suspect is innocent). That is the reason why a part of the doctrine considers the PPS as a "part/non-part" in the criminal justice system: "Part" because it takes part in the proceedings; "Non-part" because it can ask for a sanction or for an acquittal. In fact, the role of the PPS is to seek justice and not convictions.

\section{Hierarchical Organization of the PPS}

The Public Prosecution Services (Ministerio Fiscal, PPS) are headed by the State's Public Prosecutor (Fiscal General del Estado). The latter is appointed and ceased by the King upon nomination by the Government after consultation with the General Council of the Judicial Power. The person elected must be a well-known jurist with more than 15 years of experience. He/she takes office by pronouncing an oath before the King and in front of the members of the Supreme Court. As Head of the PPS, the State's Public Prosecutor proposes the members of the staff of the PPS - including their promotions and leaves - to the Government, inspects the functioning of the PPS and corrects it whenever is necessary, assures the communication between the PPS and the Government, and presents an annual report on his/her activities.

In order to accomplish these functions, the State's Public Prosecutor is helped by a a series of bodies that are presented hereafter. The functions of these bodies as well 
as those of the State's Public Prosecutor are foreseen in the Organic Statute of the PPS,

- Public Prosecution Council (Consejo Fiscal): The State's Public Prosecutor - who acts as president-, the Head of the PPS offices at the Supreme Court (Teniente Fiscal), and the Inspector Prosecutor (Fiscal Inspector) are permanent members of this Council. They are accompanied by other members who are elected among active members of the PPS for a period of 4 years. The Council establishes the general criteria to ensure the principle of unity in the work of the PPS. It also acts as a consultant to the State's Public Prosecutor. The Council has to be heard when there are proposals for members of the PPS, has to elaborate reports about the internal promotions, and can propose reforms in order to improve the functioning of the PPS. If there is a disciplinary hearing against a Public Prosecutor, the Council acts as a kind of Court of Appeal of the sentence imposed.

- Board of the Supreme Court Prosecutors (Junta de Fiscales de Sala): The main members of this Board are the Prosecutors that participate in cases brought before the Supreme Court. The Head of the Board is called the Deputy Prosecutor (Teniente Fiscal). Its basic task is to help the State's Public Prosecutor in doctrinal and technical matters. The Board is hierarchically dependent from the State's Public Prosecutor.

- Prosecution Inspection (Inspección Fiscal): Headed by the Inspector Prosecutor (Fiscal Inspector), this body exercises a task of control of the functioning of the PPS. The Prosecution Inspection is hierarchically dependent from the State's Public Prosecutor.

- Technical Secretariat of the State's Public Prosecution Services (Secretaría Técnica de la Fiscalia General del Estado): This body exercises general functions of secretariat to the State's Public Prosecutor including, for example, the elaboration of preparatory works and other studies, investigations and reports.

- Finally, the PPS has offices in each jurisdiction and at the main courts. The main offices are listed below.

- $\quad$ PPS office at the Supreme Court.

- PPS office at the National Audience.

- PPS office at the Constitutional Court.

- Special PPS office for the prevention and repression of drug trafficking: This office is specialized in drug trafficking offences and has competences all over the Spanish territory.

- Special PPS office for the repression of economic crimes related to corruption: This office also has competences all over the Spanish territory. The State's Public Prosecutor can ask other PPS offices to help and assist this special office. In addition, the PPS office for the Economic Tribunal (Tribunal de Cuentas) is integrated inside it.

- The rest of PPS offices (e.g. the PPS offices at the different provincial or local levels) and their staff are fixed through Royal Decrees (Reales Decretos). Their staff is proposed by the Ministry of Justice, but with a previous report by the State's Public Prosecutor, once being heard the Public Prosecution Council.

\section{Lack of Existence in the Spanish Criminal Justice System of Cases dealt with by the Police or the PPS}

In countries applying the opportunity principle, the police or the PPS can deal with some cases and, depending on the country, they can sometimes filed the case or even impose 
minor sanctions or measures. On the contrary, Spain applies what can be called an extended legality principle which implies not only that prosecution must take place in all cases in which sufficient evidence exists of the guilt of a suspect - a classical definition of the legality principle -, but also that the decision to file a case cannot be taken by the police or the PPS when such evidence does not exist.

The Spanish Constitution (art. 124, par. 2) establishes that the criminal justice system is ruled by the legality principle but, in fact, this principle is not used in the Constitution with the same meaning as in criminal justice studies. The legality principle mentioned by the Constitution means that all the proceedings shall start, continue and end according to what is stated in the laws. However, Spain applies also the legality principle in the sense that was explained in the preceding paragraph, and that corresponds to its use in criminal justice studies. Its origins in the Spanish criminal justice proceedings can be found in what is called the accusatory principle. As we have mentioned before, the accusatory principle states that, when a criminal offence is discovered or reported, one body should investigate the facts (Investigative Court), another should make the accusation (PPS) and another one should judge them (Criminal Court or Tribunal). This implies that the final decision about a criminal offence should always come from a court and, in principle, there is no possibility for the police or the PPS to drop or dispose cases. Indeed, this situation is a consequence of art 117 of the Constitution that establishes that the jurisdictional function belongs only to the judges.

However, as far as the PPS is concerned, its Organic Statute has introduced an exception to this rule. It concerns offences reported directly to the PPS offices. As we will see with more detail later, in such cases the PPS has extended competences to investigate the facts with the help of the police. As a consequence, if after investigation the PPS consider that there is no ground for evidence, they can file the proceedings. If the PPS files the proceedings, they must inform the citizen who reported the offence. Nevertheless, in practice, only few offences are reported to the PPS offices: citizens address themselves almost systematically to the police.

A second exception to this rule concerns the juvenile justice criminal proceedings in which, as we will see later, the PPS plays a major role.

The situation is different as far as administrative offences (i.e. offences not included in the Criminal Code) are concerned. Some of these offences such as minor driving offences and drug use in public places can be sanctioned directly by the police. However, the police can only impose fines and, if these fines are not paid, they are only allowed to seize the bank account of the fine defaulter. In this context, it is important to highlight that unpaid administrative fines cannot be converted in imprisonment. In addition, if the person does not agree with the fine imposed by the police, he/she has the right to address himself/herself to an Administrative Court (Juzgado de lo Contencioso-Administrativo). As it can be seen, criminal courts have no jurisdiction over administrative offences which, in fact, do not belong to the criminal justice system.

\section{The Investigative Stage of the Proceedings}

\section{Functions of the Police Forces During the Investigative Stage of the Proceedings ${ }^{3}$}

Spain has two state police forces, three autonomic police forces, and around 1,800 municipal forces. At the State level, and depending directly from the Government of the Nation, there are two police forces: The National Police Corps (Cuerpo Nacional de

\footnotetext{
${ }^{3}$ For a presentation of the Spanish police forces, see Aebi and Jar-Couselo (2006).
} 
Policia, CNP) and the Civil Guard (Guardia Civil). The CNP is responsible for the urban centers and the Civil Guard is responsible for the countryside. The CNP has a civil nature while the Civil Guard has a military nature. In practice, the CNP is responsible for investigation of the majority of the delinquency generated in Spain. At the present time, there are three autonomic police forces. Those of the Basque Country (Ertzaintza) and Catalonia (Mossos d'Esquadra), have tasks of security, judicial, administrative, assistance and traffic police, leaving to the State forces the rest of the tasks. In the Autonomous Community of Navarre, the autonomic police force (Policia Foral) is in charge, basically, of tasks of administrative police, traffic and transports. Finally, at the municipal level, police forces are called Local Police (Policia Local), and they assume functions of administrative police, traffic and assistance within their respective municipalities. Criminal offences - i.e. those included in the penal code - are treated by both State forces and by the autonomic police forces. Local police are competent for traffic offences and must transmit to the competent State or autonomic force all other cases in which they get involved while accomplishing their duty.

The national and autonomous police forces - and even some local police forces - have developed special units of "judicial police". These units receive their orders from the courts and, whenever the offence has been reported directly to the PPS, from the PPS. Their functions, as stated in different laws (Constitution, Code of Criminal Procedure, Organic Law of the Judicial Power), consist, among others, in arresting the offenders once the offence is discovered, helping the courts and the PPS when they need to act outside their offices, and ensuring that the decisions of the courts are being executed.

In fact, all police officers - and not only the members of the judicial police - can act according to the orders of the courts and the PPS, as well as they act according to orders received from their superior officers or by their own initiative. In this last case, if they discover the commission of an offence, they can only practice the first prevention tasks, including the seizure of the objects implied in it, and they must inform urgently the EM and the PPS.

In the case of the abbreviated proceeding (see below), judicial police units are allowed to perform other supplementary tasks such as asking the presence of doctors to bring help to the offender, take photographs or film the crime scene, or remove a dead body when it blocks the circulation in the streets. Since 2002, they also assist victims and can directly ask for help from another police force.

\section{Functions of the PPS During the Investigative Stage of the Proceedings}

As we have mentioned before - and in clear contrast with the explicit regulation for police interventions which occupy a whole title of the Code of Criminal Procedure - the competences of the PPS are not enumerated clearly. Only its role in cases when the offence is reported directly to the PPS as well as in the abbreviated proceeding are regulated in detail by the Organic Statute of the PPS. These two cases will be explained here and we kindly remind the reader that in all other cases the functions of the PPS are very limited because, as it was explained before, the investigative stage of the proceeding is under the responsibility of the EM.

\section{Offences Reported Directly to the PPS}

According to the Organic Statute of the PPS, offences can be reported directly to the PPS. In such cases, the PPS can order the police forces to intervene in order to investigate the veracity of the report. They can also conduct the declaration of the suspects in presence of their lawyer; but they cannot order cautionary measures or any measure that would imply a limitation to the 
rights of a citizen. The duration of this stage must adjust itself to the nature of the offence being investigated, but cannot exceed 6 months without permission of the State's Public Prosecutor. If the PPS decides that there is ground for evidence, they pass the file to the Examining Magistrate, who will direct the investigative stage. On the contrary, when there are no such grounds, the PPS can file the proceedings. In this case, they are obliged to transmit this decision to the citizen that reported the offence, who is allowed to report it again directly to an EM. It is interesting to note that only in this case and in the juvenile proceedings (see below the chapter on Juvenile Justice Proceedings) can the PPS file a case.

\section{The Role of the PPS In the Abbreviated Proceeding}

In the abbreviated proceeding (that will be presented later) the tasks of the PPS are extended. As a result, it is the responsibility of the PPS to impulse and simplify the proceeding, and also to promote solutions that will make a consented verdict easier to reach (i.e. a sort of plea bargaining) in cases of Less Serious Crimes.

In fact, the draft project of the regulation that introduced the abbreviated proceeding in 1988 wanted to place the PPS as a kind of parallel EM. The idea was to give to the Spanish PPS a profile that would be similar to the one of most European PPS. However, the critics coming from the bodies affected by the reform - that were extremely reluctant to it - forced the legislator to step back and the result is a weird regulation contained in one article (art. 773) of the Code of Criminal Procedure. This article is divided in two paragraphs. The first one states the general functions of the PPS in the abbreviated proceeding (to exercise penal and civil actions in the proceedings, to watch for the rights of the offender and the victim, to impulse the proceeding, to instruct the police, to ask the EM to conduct certain proofs, to adopt cautionary measures, or to conclude the investigative stage). The second one replicates article 5 of the Organic Statute of the PPS and concerns offences reported directly to the PPS, which have been treated in the previous chapter.

The Relations between the Police, the PPS and The EM: the Reality of the Investigative Stage

The relations between the police, the PPS and the EM are quite different in practice from what is stated in the law. In fact, the usual way to start a case is through the police because few people know that they can report an offence directly to the PPS. Typically, the police forces start the investigation and have the obligation to transmit their first report (atestado) to the EM, to the PPS and-except in cases when the proceeding is declared secret - to the defence lawyer. The case is then opened by the EM who can order the police to perform certain tasks in order to find the truth. However, in practice, and according to our informal interviews with police officers involved in these tasks, it is extremely rare for the police to receive instructions from the EM, and it is even more unlikely to receive them from the PPS. Usually police forces work alone and the EM and the PPS receive the different reports they produce. The exceptions concern high profile cases, in which the EM and/or the PPS play a major role since the beginning of the proceedings.

Most of the times, during the investigative stage, the PPS are not present in acts such as depositions. Therefore, their work consists mainly in studying the case according to the reports produced by the police and decide whether to ask for an acquittal or to proceed to a formal indictment. The formal indictment is usually presented in a written form. Thus, the main work of the PPS takes place during the trial stage. 
The End of the Investigative Stage

The investigative stage can reach its end in two different ways: the dismissal of the case or the opening of the trial stage. However, before the decision about the dismissal or the opening of the trial stage is taken, it is mandatory to perform two types of checks, known as the revision and the control. These checks will be presented in the following chapter, before discussing the two ways of ending the investigative stage. The goal of this presentation in three sections is to simplify the complicated panorama currently offered by the different regulations of the ordinary, abbreviated and jury proceedings included in the CCP.

\section{Revision and Control of the Investigation}

Before closing the investigative stage, two types of checks are performed. They are known as the revision and the control. The revision has the purpose of checking if the investigation has been exhaustive in relation with the offence pursued. The control has the purpose of ascertaining whether the proceedings are taking place within the appropriate jurisdiction and according to the right type of proceeding and, if that is not the case, to change them (e.g. change the type of proceeding or send the case to the competent court). Revision and control are done by the EM with the participation of the parts and, in the ordinary proceeding, the court who is going to be competent in the trial stage. Indeed, in the ordinary proceeding, the case is handed over to the court who will conduct the trial, and this court hands over the case to the parts, who can ask for further proofs. In the abbreviated proceeding, the EM hands over the case directly to the parts, who can also ask for further proofs. In the trial by jury, the rule is to send to the jury no more than what it is strictly necessary. After these checks are performed, the decision about the dismissal or the continuation of the trial can be taken.

\section{Dismissal}

The parts (PPS or defence) can ask for a total or a conditional dismissal (sobreseimiento). A total dismissal is pronounced if the investigation shows that no offence has been committed or the accused persons are not responsible. A conditional dismissal is pronounced if the proofs are not totally convincing. In both cases, the proceeding is closed without trial stage.

In the abbreviated proceeding, the decision is taken by the EM. If both parts have asked for the dismissal, the EM will usually grant it. If only the PPS has asked for it, the EM will consult the Head of the PPS office and take the final decision afterwards. In the ordinary proceeding, the decision is taken by the court competent for the trial stage. If only the PPS has asked for it, the court will consult the eventual private accusers. If there are no private accusers, the court will pronounce the dismissal.

In sum, the dismissal is asked by the parts, and is decided in the abbreviated proceeding by the EM, and in the ordinary proceeding by the court who will be in charge of the trial.

\section{Opening of the Trial Stage}

The opening of the trial stage is asked by the accusing parts (PPS and private accuser), but the criteria of the court are capital. In the abbreviated proceeding, the accusing parts will ask for the continuation of the trial by presenting the formal indictment, and the final decision will be taken by the EM. In the ordinary proceeding, the accusing parts will simply 
ask for the continuation of the trial, and the final decision will be taken by the court that is competent for the trial stage. Once the court takes its decision, the case is handed to the parts to present the formal indictment (PPS) and the defence written form (defence lawyer). In the trial by jury, the EM will ask the opinion of the parts about the continuation of the trial, and if their answer is affirmative, the formal indictment and the defence written form are asked to be brought. Later, in a preliminary audience, a debate about the continuation of the trial will be held.

\section{Cases Brought to Court}

\section{The Different Types of Criminal Proceedings}

Up to 1988, the Code of Criminal Procedure included only one type of trial called Sumario which remains nowadays the Ordinary Proceeding. That year, the CCP introduced the Abbreviated Proceeding, which is a sort of summary proceeding. This proceeding should be shorter because the offences being judged are not the most serious ones, but in practice it is not really faster than the ordinary proceeding and can last one year from beginning to end. As a consequence, in 2002, the CCP introduced the Fast Trial that constitutes the most simplified proceeding and usually lasts only a few months. Independently of their length, all these proceedings have a similar structure that corresponds to the one presented in the introduction (investigative, trial, and execution stage). The different types of proceedings foreseen in the Spanish criminal justice system are presented in a simplified way in the following chapters.

\section{Misdemeanours' Trial}

As we have already said, misdemeanours are minor offences which are punished with non-custodial sanctions and measures. Theoretically, the procedure for judging a misdemeanour - known as misdemeanour's trial (juicio de faltas) ${ }^{4}$ - has no investigative stage. It consists only in the celebration of the trial. In practice, however, there is always some activity in order to ascertain the nature of the facts. The goal is to establish, at least, if it is really a misdemeanour or not. Therefore, the structure of this particular type of criminal proceeding is similar to the ordinary one. The main difference comes from the principle of concentration of the proceeding. That principle means that the whole process takes place in one hearing. The accusation and the answer to it are done orally during the same act. This implies that the whole process (investigative stage and trial stage) are under the responsibility of the EM. It is thus an exception to the principle that different courts should be responsible of the investigative and the trial stage. This exception is justified by the fact that offences dealt with are non-serious offences and that there is always the possibility of appealing the sentence.

\section{Abbreviated Proceeding}

The abbreviated proceeding (procedimiento abreviado) ${ }^{5}$ is used when the maximum penalty for the offence being judged is imprisonment up to 9 years. The investigative stage is conducted by the EM. The trial stage is conducted by a Criminal Judge (Juez de lo Penal)

\footnotetext{
${ }^{4}$ Arts. $962-977$ of the CCP.

${ }^{5}$ Arts. $779-799$ of the CCP.
} 
if the maximum potential sanction is lower than 5 years imprisonment. When the maximum potential sanction goes from 5 to 9 years, the trial stage is conducted by the Provincial Criminal Tribunal (Audiencia Provincial), which is a collegiate Court. The difference with the ordinary proceeding comes from the fact that the proceeding is shorter because the offences being judged are not the most serious ones and, therefore, the investigative stage usually requires less time. As we will see later, the PPS play a more active role in this kind of proceeding than in the ordinary one.

\section{Trial by Jury}

The trial by jury was introduced in 1995 and is used for a series of offences stated in the Organic Law (5/1995) that established it. These offences include, among others, intentional homicide, threats, and some sorts of fraud. The investigative stage is under the responsibility of the EM. The trial takes place before a jury and under supervision of a magistrate from the Provincial Audience. The jury reaches a verdict and the magistrate imposes the sentence.

\section{Ordinary Proceeding}

The Code of Criminal Procedure Code dedicates most of its articles to the ordinary proceeding (procedimiento sumario). This constitutes a paradox because, in practice, it has become the residual proceeding (i.e. the one that is used when no other proceeding is possible). Nevertheless, the ordinary proceeding - which was the only proceeding until 1988 - is still considered by the law as the standard one, and the rest of the proceedings are regulated in reference to it. It is used for Serious Crimes (i.e. offences punishable with imprisonment for more than 9 years). The investigative stage is conducted by the EM. The trial stage is conducted by the Provincial Audience.

\section{Fast Trial}

As its name suggests, the fast trial (juicio rápido) ${ }^{6}$ implies a simplified proceeding. It was introduced in 2002 in order to reduce the length of the criminal procedures that was being pointed out as one of the main weaknesses of the Spanish criminal justice system. As a consequence, the whole proceeding is guided by the idea of accelerating the criminal procedure.

In order to apply the fast trial proceeding, the case must fulfil three conditions:

1. The maximum penalty for the offence being judged is imprisonment up to 5 years.

2. The proceeding has been started by a police report and the suspected offender is known to the police. Either the police have arrested the person and placed him/her at the disposal of the court, or the person has the obligation to present himself/herself before the Court as a suspected offender.

3. The case must comply with any of the following circumstances:

a. The offence was detected on the spot (in fraganti). This means that the suspect is identified while committing the offence or immediately after having committed it

\footnotetext{
${ }^{6}$ Fast trials are regulated in title III (arts. no. 795 a 803), Book IV of the Code of Criminal Procedure, introduced through law 38/2002, and Organic Law 8/2002.
} 
(either after a pursuit or when the person has objects, instruments or traces that allow to presume his/her participation in the crime).

b. The offence is one of the following ones: (1) injuries, constraints, threats or physical or psychic habitual violence, committed against members of the family; (2) theft without the use of force or intimidation (hurto); (3) theft with the use of force or intimidation (robo); (4) theft of use of vehicles; (5) traffic offences; (6) some types of damages (art. $263 \mathrm{CC}$ ); (7) Crimes against the public health (art. $368 \mathrm{CC)}$ (8) Crimes against the intellectual and industrial property (arts. 270-275 of the CC).

c. It is anticipated that the investigative stage of the proceeding will be quite simple.

As it can be seen, the fast trials proceeding applies to cases where the investigative stage is supposed to be simple and can be arranged easily by an EM in only one audience. The case is presented directly to the Investigative Court who is on shift (Juzgado de Guardia). As always, the EM is responsible for hearing the detainees within 72 hours of his/her detention. The PPS participate in the hearing and can ask the judge to apply some cautionary measures. Immediately after the hearing, the accusation (by the PPS) and the defence (by the defence lawyer) are presented orally or in a written form. However, the defence can ask for a 5 days delay in order to prepare it. Both statements will indicate, among other things, the type of offence they consider the act was, the penalty asked and the particular circumstances of the act. After hearing the accused and receiving the statements, a date is appointed for the trial, which will take place before a Criminal Judge (Juez de lo penal).

Furthermore, the reform foresees an ultra-fast proceeding. Once the accused knows the accusation written by the PPS, a sort of plea bargain can take place with his/her defence lawyer and if they arrive to an agreement, the EM can impose the sentence without going to trial. The benefit of this sentence is that it includes a reduction of $1 / 3$ of the sanction that would normally be imposed. However, the law asks that four conditions must be met in order to allow such proceeding.

1. The PPS must have presented the written accusation, and there is no private accusation.

2. The offence must be punishable with a sanction up to 3 years imprisonment.

3. After reduction, the sanction imposed must not exceed 2 years imprisonment;

4. The EM must verify that the accused person is giving his/her conformity to the sanction.

The sentence is then dictated orally, and the parts agree to waive appeal.

As we can see, the fast trial respects basically the structure of the ordinary proceedings but in a concentrated way. The investigative stage takes place before the EM while the trial stage takes place before a criminal judge in the case of the fast trial and before the same EM when the ultra-fast proceeding is possible. This latter possibility has been criticized because it implies an exception to the rule of the two instances and may harm the accused rights. Their supporters justify it by pointing out that the accused person accepts the sentence.

\section{Comparative Table}

Table 1 summarizes the different proceedings.

\section{Role of the PPS in the Cases Brought to Court}

As it has been stated before, the different laws mentioning the PPS do not indicate clearly its functions. Therefore, we are presenting here a list of the functions that a Public 


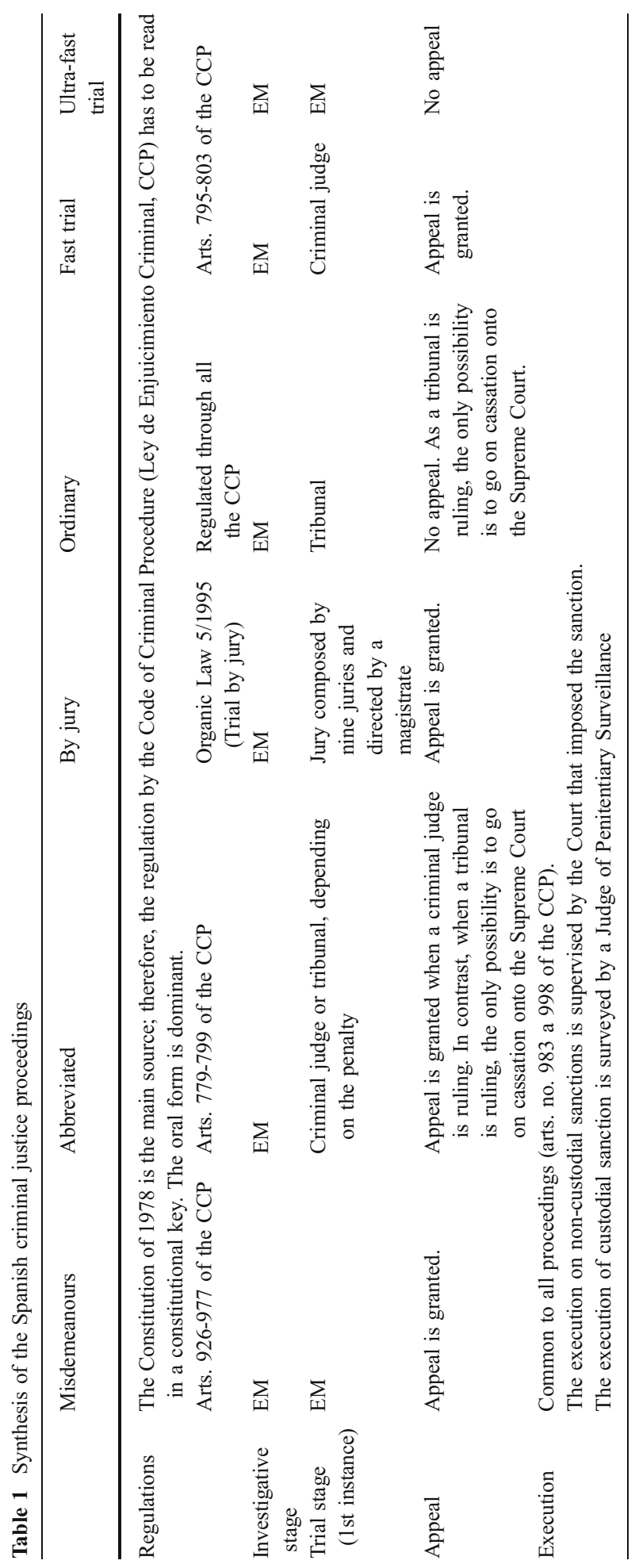


Prosecutor is likely to have in the different proceedings, paying special attention to the plea bargain process.

In that context, it is interesting to point out that plea bargain is not "officially" recognized in the CCP. However, the CCP foresees an exceptional way of ending the case by achieving an "agreed sentence" (juicio de conformidad) which is, in fact, the result of a plea bargain. This exceptional proceeding applies to the fast trials in which, as we have seen before, the accused person can accept the accusation of the PPS under some circumstances, and as a consequence the sentence will be reduced in one third. A more general application of it concerns the proceedings for Misdemeanours and Less Serious Offences in which an internal order coming from the Head of the PPS (which dates from 1989, after the regulation of the abbreviated proceeding) asks the PP to look for consensual solutions with the defence.

\section{Role of the PPS in the Non-Fast Trials}

In normal cases, (misdemeanours, abbreviated, jury or ordinary proceedings), the PPS is in charge of bringing the accusation to the court judging the case.

In the case of the misdemeanours and the abbreviated proceedings, an informal negotiation (plea bargain) is usually done through a meeting of the PPS and the defence lawyer that takes place a few minutes before the beginning of the trial. If consensus is reached, the judge dictates the sentence orally (in voce), and the parts waive its right to appeal. The judge cannot dismiss the consensus because he/she is entitled to rule within the limits asked by the parts and, in this case, the limits are the ones reached through the plea bargaining.

The rest of the functions of the PPS during these proceedings is similar to the functions of the defence lawyer. They include presenting the case orally and asking questions to the witnesses. The PPS also presents the final argumentations resuming their position in the case, and they have the power to modify the charges in the final stage of the trial. Finally, when the sentence is not the one asked by the PPS, they have the right to appeal whenever this option is possible.

\section{Role of the PPS in the Fast Trials}

The role of the PPS in this simplified proceeding is essentially the same but in a concentrated way.

The only exception is the ultra-fast trial in which, as plea bargain has to be achieved, the role of PPS is reduced to write the accusation and negotiate with the defence. It is important to note that the accusatory principle is still valid in those proceedings. This means that the judge is obliged to accept the consensus agreed by the parts.

\section{Particular Issues}

In the following chapters we will analyze the role of the victim in the criminal justice system as well as the juvenile justice proceedings. In the latter, the function of the PPS differs radically from what we have presented until now.

\section{Victim Participation}

The rise of the Crime Victims Movement during the last quarter of the 20th Century led to a strong critique of the role played by victims in criminal justice proceedings. Most criminal 
justice systems have been accused of having "forgotten" the victims, and Spain is no exception to this rule. As everywhere else, judges, public prosecutors, lawyers and police officers have been accused of acting according to their own interest and without paying attention to the victim or his/her relatives. A revision of the legal codes showed that they did not talk about "victims" but about "passive subjects". Observation of the role played by victims also showed that they tended to play a role similar to the witnesses: they were there mainly to present their version of the facts. The concept of "secondary victimization" (i.e. the trauma suffered by victims due to the insensitive behaviour and attitudes of the different bodies of the criminal justice system) have also been evoked quite frequently. ${ }^{7}$

In reaction to these critiques, and following partially some of the Recommendations of United Nations to improve the role of victims in criminal justice proceedings, the Autonomous Communities started to implement their own Victims Assistance Agencies. Most of these agencies are run by non-governmental organizations with the support of public funds. They usually have a team composed by psychologists, social workers and lawyers that can provide help and orientation to crime victims. Currently, victims of violent crime that report a crime to the police should be systematically informed about the existence of these agencies. In practice, most of the cases treated by these agencies concern domestic violence.

On the other hand, few modifications were introduced to the legal texts. The fact that the offender repairs the harm done to the victim is contemplated as a mitigating circumstance; but this leads to an ambiguous situation because it is not possible to establish the real motivation of the offender to do so (in some cases he/she may act like that only to invoke the mitigating circumstance). In practice, the role of the victim during the criminal justice proceeding has not really changed. Moreover, the introduction of plea bargains through an "agreed sentence" (juicio de conformidad) has somehow reduced the role played by the victims in such proceeding. In fact, they are often informed a few minutes before the beginning of the trial that an agreement has been reached and their presence (and declaration) is no longer necessary.

The contact of the victim with the PPS is also very limited. Most of the time, the victim will not know the name of the Public Prosecutor in charge of his/her case or the ways to contact him/ her. Thus, the victim and the Public Prosecutor usually meet only the day of the trial.

Finally, it must be mentioned that victims of terrorism have gathered themselves through associations but, unfortunately, in recent years these associations have been heavily politicized.

Mediation programs for juvenile offenders have been introduced and will be discussed in the following chapter.

\section{Juvenile Justice Proceedings}

\section{General Overview ${ }^{8}$}

The Criminal Code applies only to persons aged 18 or over. A new juvenile delinquency law was introduced in 2000. It regulates the penal responsibility of juveniles aged 14 to 17 , creating a new and unique proceeding for them. If the offender is under 14, the Civil Code states that the public administration will take care of him/her, promoting whatever protection measures are needed according to the circumstances. There is also a possibility of treating as juveniles persons over 18 and under 21 when the offence is a Misdemeanour or a Less Serious Offence, when the offender has no previous records of offences

\footnotetext{
${ }^{7}$ For details, see Garrido et al. (2001).

${ }^{8}$ For a detailed presentation of the juvenile criminal justice in Spain, see de la Cuesta $(2001,2002)$, OrnosaFernández (2005), Rechea-Alberola and Fernández-Molina (2006).
} 
committed after turning 18 years old, or when the personal circumstances of the offender and his/her maturity degree recommends it. The competence of this proceeding falls upon the Juvenile Courts (Juzgados de Menores).

Constitutional rights of the minor are guaranteed in this type of proceeding, but there is an essential difference with the adults' regime: the penal responsibility of the juveniles leads to an educative intervention which is present all along the proceeding. The main characteristics of this proceeding are the following.

1. The nature of the proceeding is formally criminal but materially educative;

2. All constitutional rights are respected, and the most important principle is the interest of the minor;

3. The adoption and execution of the measures are based on the circumstances of each case;

4. The execution of the measures is done by the Administration, but controlled by the Juvenile Court.

\section{The Key Role of the PP in the Juvenile Jurisdiction}

The juvenile proceeding is the only jurisdiction where the PPS has a pre-eminent role. According to the law, the PPS are in charge of defending the rights of the juvenile, and therefore the surveillance of the whole investigative stage, which is directed by them. One of the functions of the PPS is to evaluate the behaviour of the juvenile offender in order to establish the punishment he/she deserves. Theorists have criticized this statement, because it is not a typical function of the PPS. The PPS also propose the measure (medida) adapted to the offence committed (as far as juveniles are concerned, all sanctions are called measures).

Unfortunately, the law (art. 23) does not include a clear description of the tasks of the PPS during the investigative stage of the proceedings. It does not state anything related to the declaration of the offender, or the victim, or the witnesses. In addition, the article does not fix the estimated duration of the investigative stage, which is one of the toughest problems of the Spanish criminal justice system.

All acts of the PPS that lead to a restriction of fundamental rights have to be communicated to the juvenile judge, who has to approve them and practice them by himself/herself. Another consequence of the PPS being in charge of the investigative stage is that they have the prerogative to give orders to the police to ascertain the facts, and that the PPS dispose of a technical team formed by psychologists, social workers and other specialized persons that will inform them about the situation of the minor (familiar, social, educative and other).

In sum, the PPS is in charge of the investigative stage, while the juvenile courts are responsible for the trial and the execution stages of the proceedings.

\section{Brief Description of the Juvenile Justice Proceedings}

The proceedings start when the offence is reported to the PPS either directly or through the police. In practice, and as we have already mentioned, most offences are reported first to the police, who informs the PPS whenever a person aged under 18 is involved.

The PPS has to decide whether the facts are constitutive of an offence or not. If the offender is unknown or the facts are not considered an offence, the PPS can drop the case. If the offence is a Misdemeanour or a Less Serious Offence committed without violence or intimidation, and the offender has no criminal record, the case can be transferred from the 
criminal jurisdiction to the administrative one. In that case, the PPS pass the case to the Public Administration, who can adopt whatever measure they consider appropriate. Finally, if the PPS decide to continue with the investigation, they must inform the juvenile court - who opens the pertinent file - and ask the technical team to establish a report about the suspected juvenile offender.

During the investigative stage, victim-offender mediation can take place under the supervision of the PPS.

When the investigative stage is concluded, the PPS can ask the juvenile judge to drop the case or to open the trial. The case can be dropped according to the general regulations of the CCP presented before (e.g. the investigation shows that no offence has been committed) or because a victim-offender mediation has been successful, or because the technical team suggests so, taking into account the circumstances of the offence or the minor. However, the final decision about dropping the case belongs to the juvenile judge.

If the PSS consider that the proceeding should continue, they must write the formal indictment. The defence lawyer also presents his defence in a written form.

In the trial stage, there is always a first attempt to reach an agreed sentence. If this works and the defence accepts the measure proposed by the PPS, the judge will pronounce the sentence orally and the parts will waive appealing. Otherwise, the trial will continue according to the classic structure described at the beginning of this article. The sentence of the juvenile court can be appealed by both parts.

Finally, the execution stage is in charge of the Autonomous Communities. Thus, the Autonomous Administration will execute the measure, under control of the juvenile court that imposed it.

The execution of the sentence can be suspended. Moreover, sentences imposed to juveniles are registered only in a Registry of the Justice Department which is accessible only to judges and public prosecutors. Therefore, there are no public records of the offences committed by juveniles.

\section{Current Changes}

Doctrinal discussions about possible direct or indirect legislative changes that would affect the PPS, usually turn around two main topics: the possibility of extending the role of the PPS during the investigative stage of the proceeding, and the introduction of the opportunity principle in the criminal proceedings.

Regarding the role of the PPS during the investigative stage, the main question is whether a Public Prosecutor directing this stage would guarantee the safety of the proceedings as established in the Constitution. Supporters of this change suggest that investigations conducted by the PPS could be more efficient as the ones directed by a judge, who is obliged to control constantly the legality of the investigative measures adopted. Currently, investigative acts are considered proofs and must be reproduced at the trial stage (e.g. the victim will eventually testify first before the police, then before the EM, and a third time before the court), but if the investigative stage would be directed by the PPS, they would not be allowed to generate proofs (which will only be produced once, during the trial stage). Furthermore, this model would have two other important benefits. First of all, it will allow a faster investigation through the elimination of some unnecessary steps. Second, the investigative stage would be changed by a preliminary one, in charge of the PPS but under judicial control, and thus the main phase of the process will be the trial stage, where proofs have to be presented and where the defence and the PPS would have equal rights. 
Concerning the opportunity principle, some authors have pointed out the advantages of implementing it in the Spanish criminal justice system. Among the advantages, it is often mentioned that it would lead to an improvement in the application of the principle of minimum intervention of the criminal law (because the PPS would decide individually according to the specific parameters of each case and thus avoid to bring to court cases that do not deserve it). It has also been stated that the principle of equity would be better served, because the opportunity principle allows having different responses to different cases which require different treatment. Some authors also consider that it would eradicate the discretionally existing in some parts of the process. Finally, it is hoped that the opportunity principle will collaborate to reduce the collapse in the number of cases being treated by the courts.

In practice, and as it has been pointed out throughout this article, the main problems of the Spanish Criminal Justice System are the amount of cases that have to be dealt with by the courts and the length of the criminal justice proceedings. Thus, the extension of the powers of the PPS as well as the introduction of the opportunity principle could provide a solution.

However, the introduction of the opportunity principle would be extremely complicated to achieve. It would require a change of the Constitution, which constitutes an extremely delicate matter, as well as a whole rethinking of the logic of the criminal proceedings.

Concerning the role of the PPS, their functions has been extended gradually since the end of the 1980s but, as we have already mentioned - the only attempt to change radically its role (in 1988) was rejected, and the members of the PPS were specially reluctant to such a change. The reasons for that rejection could be related to a general human mistrust in changes, a kind of tendency to inertia aggravated in the case of public servants who benefit of the stability of their jobs.

Thus, the suggestions for changes come mainly form the academic world. In fact, nowadays there are no signals that major changes will be attempted in the years to come.

\section{Conclusion}

Traditionally, the role of the PPS in Spain has been very limited during the investigative stage of the process. That stage is under the responsibility of the EM. Since the end of the 1980s, a series of modifications has been introduced in order to extend the functions of the PPS. With the introduction of the abbreviated proceeding in 1988, the PPS received extended competences which allow them to receive reports of offences. Thus, if an offence is reported to the PPS or if the PPS comes to know that an offence has been committed, they can initiate the proceeding. With the introduction of the fast trials in 2002, another step was taken in the same direction, and the PPS were allowed to lead a sort of plea bargain under a series of restrictive conditions and only for some offences. Currently, plea bargain also exists in the misdemeanours and abbreviated proceedings. In all cases, the plea bargain is achieved through an "agreed sentence" (juicio de conformidad). At the same time, the PPS has received extended competences in the juvenile justice criminal proceeding in 2000. Figure 1 presents a simplified model of the Criminal Justice in Spain that summarizes what have been said in this article.

However, the role of the PPS has not changed radically and, during the investigative stage of the process, their main role remains the presentation of the accusation. On the contrary, they played a more active role during the trial stage of the proceeding. 

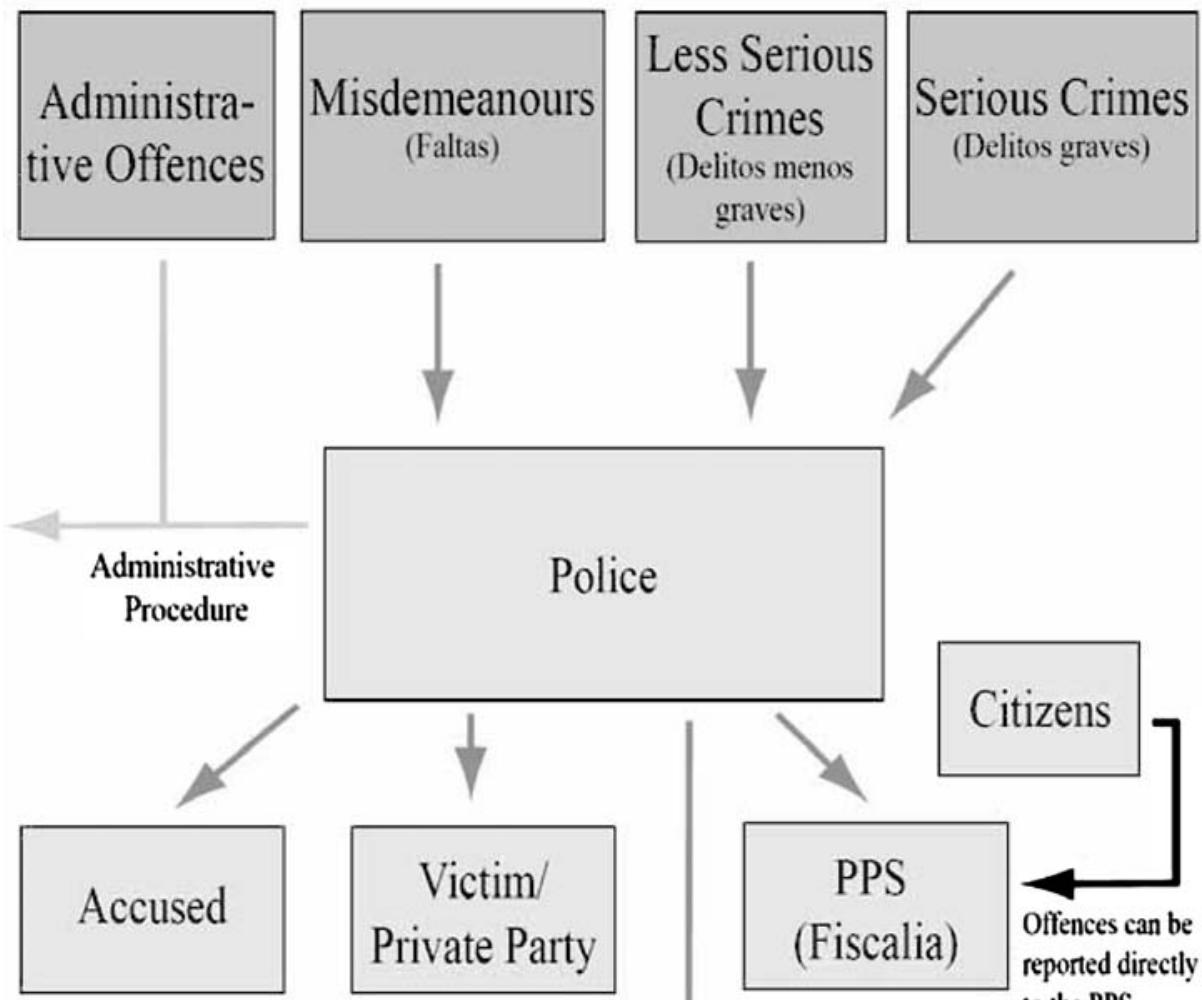

Unless the cause is considered secret by the EM, all the parties can access to the information at the same time

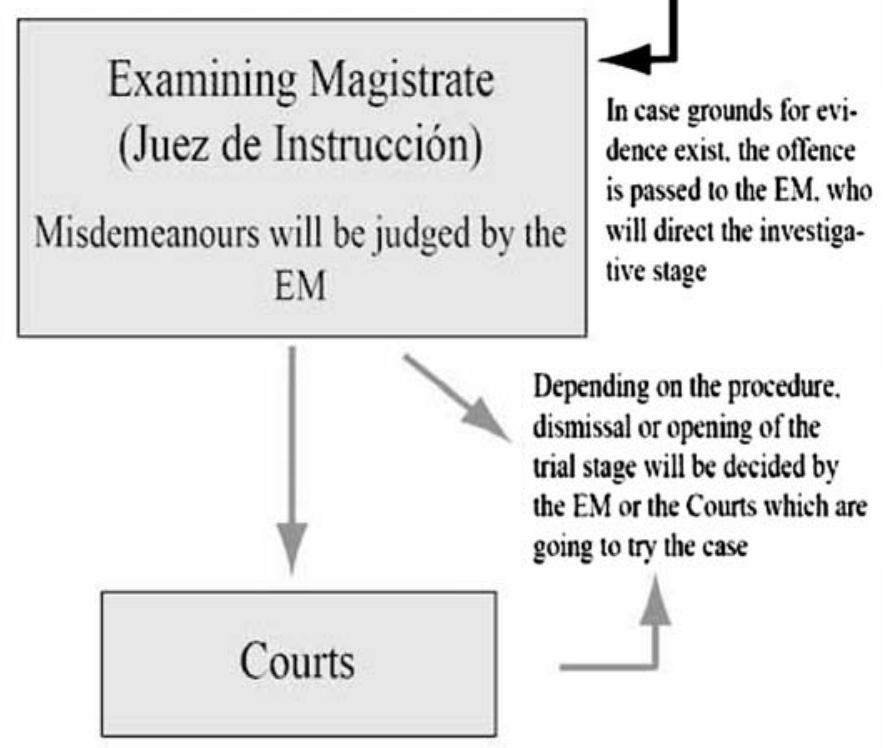

Fig. 1 Simplified model of the criminal justice system in Spain 


\section{References}

Aebi, M. F., \& Jar-Couselo, G. (2006). Spain. In D.K. Das (Ed.), World police encyclopedia (pp. 773-780). New York: Routledge.

Conde-Pumpido Ferreiro, C. (1999). El Ministerio Fiscal. Navarra: Ed. Aranzadi.

de la Cuesta, J. L. (2001). The position of victims and victim support in the new Spanish juvenile criminal law. In E. Fattah, \& S. Parmentier (Eds.), Victim policies y criminal justice on the road to restaurative justice. Essays in Honour of Tony Peters (pp. 59-82). Leuven: Leuven University Press.

de la Cuesta, J. L. (2002). El nuevo derecho penal juvenil español del siglo XXI. International Annals of Criminology 40, 1-2, 53-72.

de la Oliva Santos, A., Aragoneses Martínez, S., Hinojosa Segovia, R., Muerza Esparza, J., \& Tomé García, J. A. (2005). Derecho procesal penal, 7th ed. Madrid: Ed. Universitaria Ramón Areces.

Flores-Prada, I. (1999). El ministerio fiscal en España. Valencia: Ed. Tirant Lo Blanch.

Garrido, V., Redondo, S., \& Stangeland, P. (2001). Principios de criminología. 2nd ed. Valencia: Ed. Tirant Lo Blanch.

Ornosa-Fernández, M. R. (2005). Derecho penal de menores, Second edition. Barcelona: Ed. Bosch.

Ramos-Méndez, F. (1997). El sistema procesal Español, 3rd ed. Barcelona: Ed. Bosch.

Ramos-Méndez, F. (2000). El proceso penal, 6th ed. Barcelona: Ed. Bosch.

Rechea-Alberola C., \& Fernández-Molina E. (2006). Continuity and change in the Spanish juvenile justice system. In J. Junger-Tas, \& S. Decker (Eds.), International Handbook of Juvenile Justice (pp. 325-350). New York: Springer-Verlag, 325-350. 